\title{
Jane Austen and the Council of the Federation
}

\author{
Jean Leclair
}

As I was preparing this article ${ }^{1}$ about the Council of the Federation, about the manner in which it differed from its predecessor, the Annual Premiers' Conference, my thoughts were constantly harking back to my favorite English author, Jane Austen. Although the titles of her novels are different, and despite the fact that Elizabeth Bennet is not an exact replica of Elinor Dashwood, ${ }^{2}$ Jane Austen always writes the same story: the battle between reason and emotion, between sense and sensibility. Now, quite frankly, as do Alain Noël and others before me, I believe that the Council of the Federation is not more than a light institutionalization of the Annual Premiers' Conference. ${ }^{3}$ It is the same story again. And one that also has to do with the tension between sense and sensibility. During my preparation, I also recalled the very first sentence of Jane Austen's masterpiece Pride and Prejudice which runs as follows: "It is a truth universally acknowledged, that a single man in possession of a good fortune, must be in want of a wife." Amusingly, the Council of the Federation's philosophy could be articulated in a similar fashion: "It is a truth universally acknowledged, that a federal government in possession of a good fortune, must be in want of provinces."

After briefly describing the political context that led to the creation of the Council, I will try to evaluate its potential as a means of "revitalizing the Canadian Federation and [of] building a more constructive and co-operative federal system." ${ }^{4}$ Such success, I believe, greatly depends on the provinces' willingness to pool their sovereignties, and thereby trade their competitive understanding of federalism for a more collaborative one. Furthermore, being an intergovernmental body within the executive branch of government, ${ }^{5}$ the Council's potential as a mechanism for renewal is hampered by the democratic deficit from which it suffers. Finally, the non-constitutional soft-law character of the agreements, brought to life under the aegis of the Council, is an inappropriate remedy for questions of symbolism, recognition and identity. I will round up these preliminary comments by explaining how the European Union's Open Method of Coordination could help improve the Council.

\section{Some Background Information: Executive Federalism in Canada}

The legislative powers distributed to the central government and the provinces, under sections 91 and 92 of Canada's 1867 federal Constitution, ${ }^{6}$ are said to be "mutually exclusive." Therefore, the division of powers guarantees the autonomy of both levels of government, and more particularly, that of the provinces. It is also agreed that those sections grant legislative jurisdiction "in relation to" certain matters within the enumerated classes of subjects. In short, exclusivity is a concept related to the types of legislative purposes that can be fulfilled by exercising a given power. Envisaged in such a manner, the exclusivity principle does not prevent the two orders of government from legislating over the same issue. ${ }^{7}$ When a statute 
relates to a subject matter that falls under a head of federal jurisdiction, when viewed at from one angle, and a head of provincial jurisdiction, when viewed at from another angle, courts conclude that the subject has a "double aspect." Legislation on such a subject can therefore be passed by either Parliament or a province, insofar as each is pursuing a purpose that lies within its jurisdiction. ${ }^{8}$ For example, "environmental protection" is not expressly mentioned in either sections 91 or 92 of the Constitution Act, 1867. However, both levels of government can promote the protection of the environment by resorting to their respective heads of exclusive jurisdiction. The central government, endowed with the exclusive power to enact "criminal law" (section 91(27)), can prohibit any activity detrimental to the environment's integrity. Provinces can achieve the very same objective by regulating local industrial activities that pollute the environment, such activities falling within the purview of their exclusive jurisdiction over "property and civil rights" (section 92(13)). ${ }^{9}$

Thus, courts have developed an understanding of federalism that is sensitive to both the need for autonomy (the exclusivity principle), and to the inescapable demands of interdependence (the aspect and double aspect doctrines). ${ }^{10}$ It is not, however, the role of courts to manage the day-to-day consequences of this interdependence. Consequently, intergovernmental bodies had to be created. Importantly, these informal arrangements have no foundation in statutes, conventions of parliamentary government, or the Constitution. They have provided the channels through which intergovernmental negotiation, in general, and constitutional adaptation, in particular, were made possible. Arrangements such as the First Ministers' Conferences (annual federalprovincial conferences of the provincial Premiers and the federal Prime Minister), the Annual Premiers' Conference (replaced in 2003 by the Council of the Federation), the Western Premiers' Conference, the Atlantic Premiers' Conference, and the meetings of standing federal-provincial committees of finance ministers and line ministers have all given birth to what is generally referred to as "executive" and "interstate" federalism.
In the words of J. Peter Meekison, "From an institutional perspective the key distinction between interstate and intrastate federalism is how the provincial voice is expressed, through an intergovernmental forum or through a restructured upper house."11 In Canada, the ever-growing importance of executive and interstate federalism lies in the dismal failure of intrastate federalism.

The Canadian Senate, whose members are appointed by the Prime Minister on the basis of pure patronage, is "not a provincial chamber, like the German Bundesrat, but a partisan one." 12 The failure of the Senate to adequately represent the regions only reinforces the provincial premiers' claims that they are the only legitimate voice of their constituents. Furthermore, Canada's British Westminster style of governance, which is based on a first-past-the-post electoral system, a fusion of legislative and executive powers, party discipline, and ministerial solidarity, has lent support to the establishment of allpowerful executives at both the provincial and federal level..$^{13}$ Party discipline, in particular, makes it impossible for individual members of the governing party to express the wishes and preferences of their region's constituents where these do not meet with the approval of Cabinet. All these elements prevent Parliament (the Senate and the House of Commons) from performing its role as an inter-regional bargaining forum. ${ }^{14}$ Moreover, whereas national political parties have traditionally tried to make their deputation representative of the regional, linguistic, and ethnic diversity of Canada, we have witnessed in recent years a regionalization of party politics, with the Conservative Party representing mostly Western Canadian interests and the Bloc Québécois intent on promoting Quebec's right to secede from Canada. In short, since intergovernmental relations cannot take place within the federal institutions, they must therefore take place between governments. ${ }^{15}$

In addition, the failure of the 1987 Meech Lake Accord and the 1992 Charlottetown Accord has demonstrated that the cumbersome mechanism established by the amending formula of the Constitution Act, $1982^{16}$ makes major constitutional reforms impossible. 
Formally amending the Constitution to improve intrastate federalism is thus out of the question in the near future. In the present context, the non-constitutional path is the only politically feasible avenue of reform in Canada. Since the 1992 referendum, the " $C$ " word is anathema in our country.

Therefore, although it has been criticized as "contribut[ing] to undue secrecy in the conduct of the public's business" and "to an unduly low level of citizen participation in public affairs," and although it has been said to "weaken and dilute the accountability of governments to their legislatures and to the wider public,"17 executive federalism remains the only available channel through which the provinces can voice their concerns over national affairs. And since "national affairs" in the central government's understanding seems to be more and more synonymous with "intraprovincial matters," the provinces are understandably searching for an efficient, albeit non-constitutional, institution to check the federal government's insatiable appetite for power.

According to the exclusivity principle, the central government is not allowed to legislate over matters falling within the purview of the provinces. However, under the guise of its spending power, the federal government can achieve the very same result. Indeed, conditional grants have proven a successful means of regulating matters falling within provincial jurisdiction. One must bear in mind that, in Canada, the fiscal power of the federal government has always far exceeded that of the provinces. As such, its spending power, unobstructed by the fragile legal framework imposed under intergovernmental agreements, has enabled it to encroach upon the exclusive heads of power of the provinces. Although such power has been the subject of much criticism, Ottawa is not willing to relinquish its spending power in areas of provincial jurisdiction. Parliament's enumerated powers, despite being generously interpreted by the Supreme Court of Canada in recent years, ${ }^{18}$ are still primarily concerned with specific and technical matters: criminal law, banking, navigation and shipping, interprovincial and international trade and commerce, etc. None of these subject matters are electorally appealing. On the other hand, the spending power allows the central government to involve itself in issues that matter to the average Canadian, such as health and education. "Ottawa . . . seeks public credit for leadership and funding on matters that are profoundly important to all Canadians." 19 The central government has even gone so far as to completely bypass provincial governments by unilaterally introducing direct spending programs in areas of provincial authority (i.e., the Millennium Scholarship Fund, Canada Research Chairs, Canada Foundation for Innovation, Medical Equipment Trust Fund, Canada Child Tax Benefit, and various transfers to municipalities, etc.). ${ }^{20}$

Even though federal transfers certainly have been instrumental in providing Canadians with a "high minimum level of important social services,"21 they have undoubtedly affected the distribution of legislative powers in Canada. And provinces are not in a position to refuse the funds, even though they might strongly disagree with the conditions attached to them. Moreover, the intergovernmental agreements that form the basis of these spending programs are extremely vulnerable to the unilateral action of the signatories. The Supreme Court has concluded that the principle of parliamentary sovereignty authorizes Parliament to renege on a promise made to a province in an intergovernmental agreement. $^{22}$

Although not initially designed for this task, the Annual Premiers' Conference (APC) became the intergovernmental body whose primary purpose was to curb this type of federal invasion. Between 1887 and 1926, these interprovincial conferences were held sporadically. They fell into disuse after 1926 until their resurrection by Quebec's Premier Jean Lesage in 1960. Since then, they have become annual events. In 1960, Ontario's Premier, Leslie Frost, reportedly said that he wanted "to restrict [these] meetings to provincial matters," and insisted "there must not be any ganging-up on Ottawa." ${ }^{23}$ Be that as it may, after a review of the APC's accomplishments over the years, J. Peter Meekison concludes that "the focus of the APC 
since its formation in 1960 has gradually shifted away from the discussion of interprovincial issues. The conference is now primarily concerned with policy issues that reflect the current state of federal-provincial relations." ${ }^{4}$ Former Ontario Premier Bob Rae puts it more bluntly: “The Annual Premiers' Conference, particularly in the late 1990s, was nothing more than a highly ritualized commentary and denunciation of how the federal government should do its job."25

The Council of the Federation has been portrayed by those who brought it to life as an entirely new institution - one that "replaces the Annual Premiers' Conference and goes much further." 26 This institution would not fall into the "ganging-up on the federal" trap. According to them, the Council would enable the provinces to collaborate as they had never previously done. In the words of Quebec Premier Jean Charest: "Ça va, pour la première fois, amener les gouvernements provinciaux à travailler en étroite collaboration à un niveau jamais connu auparavant. C'est peut-être un peu surprenant qu'on ne l'ait pas fait avant." ${ }^{27}$

Benoît Pelletier, Quebec's intergovernmental affairs minister, emphasized that federal bashing was out of the question: "Il faut que cela fasse contrepoids au fédéral. C'est ça le but. Mais cela doit se faire d'une façon positive. On ne veut pas d'une institution négative, qui ne fasse que se plaindre ou qui fasse du 'federal bashing."’28

In other words, because formal constitutional reforms are impossible, the renewal of the federation will be made possible, according to Pelletier, by "a non-constitutional institution" 29 where provinces and territories, represented by their premiers, ${ }^{30}$ "as necessary partners . . . will progressively develop their own vision of what Canada should become, and firmly consolidate their rightful place within our country." ${ }^{31}$

Whether this "new" institution will meet with success greatly depends on what the premiers seek to achieve. What is their understanding of a "more constructive and cooperative federal system"? ${ }^{32}$ The Council is meant "to make Canada work better for
Canadians," 33 but how are the latter's voices to be heard if the Council "comes under the executive branch, rather than the legislative branch, of the provincial and territorial governments"? ${ }^{34}$ Will this institution be successful in dealing with issues of Québécois or Aboriginal identity? These are the questions I will now briefly address.

\section{The Council of the Federation: A Light Institutionalization of the Annual Premiers' Conference}

As I said in the introduction, the Council of the Federation is not very different from the Annual Premiers' Conference. Notwithstanding the wording of the founding agreement, they share the same degree of institutionalization, given that the conception of federalism underlying both the APC and the Council is one based on competition and not on collaboration and cooperation.

Had the Council been built around a truly collaborative model of federalism, it would have displayed a much higher degree of institutionalization. In the words of Martin Papillon and Richard Simeon:

Thecollaborativemodelthat seesgovernance
in Canada essentially as a partnership
between two equal orders of government
that collectively work together to serve
the needs of Canadians... emphasizes the
need for co-operation, harmonization, and
mutual agreement on common values and
standards.

As the authors underscore, such a model demands the issuing of binding decisions and the establishment of enforcement mechanisms. On the other hand, "a more competitive view of Canadian federalism... stresses the importance of autonomous governments, acting on their own within their jurisdictional limits, to meet the needs of their own electorates." ${ }^{36}$ As such, it is based on "vigorous intergovernmental competition, and a wide diversity of policy responses . . ." "37 Importantly, "[i]n this model, co-operation is not the holy grail; it may even result in 'lowest common denominator solutions' 
that please no one." 38 Binding enforcement mechanisms are strangers to the competitive model.

As was the case with the APC, and contrary to the initial wish of Quebec's intergovernmental affairs minister Benoît Pelletier, the decisions of the Council will be reached by consensus rather than by majority vote. ${ }^{39}$ No improvements were made to the APC's institutional features. There is no mention of qualified majority votes, mirror legislation for the implementation of interprovincial agreements, or disputesettlement mechanisms. And as was the case in 1973 for the Canadian Intergovernmental Secretariat, the Council secretariat will not serve as an instrument of research, analysis, and prescription; its task shall simply be "to assist the Steering Committee - composed of Deputy Ministers responsible for intergovernmental relations - in the preparation for meetings of the council." ${ }^{30}$ Pelletier has recently lamented over the inefficiency of the secretariat. ${ }^{41}$

Furthermore, a truly collaborative model of federalism would involve both a partnership between the two orders of government where federal-provincial issues are concerned and a partnership among the provinces themselves where intra- and interprovincial issues are at stake. As it stands, the federal government is not part of the Council. Consequently, even though the provinces might succeed in building a common front against the federal government, the arrangement will not necessarily promote collaborative federalism since the Council's power is limited to recommending a solution to the federal government. Ottawa still holds the big end of the financial stick. So much so, in fact, that it can easily destroy provincial common fronts. Small and poor provinces are particularly vulnerable to the federal "divide and conquer" strategy. The 1999 Social Union Framework Agreement, signed by the federal government and all the provinces, except Quebec, is a good example of Ottawa's successes when it strategically resorts to its fiscal leverage to sway poorer provinces to walk its way.

The power of the Council over federalprovincial affairs will be all the more fragile, since the Council is negotiating with an unpredictable partner. Ottawa's case-bycase approach to intergovernmental issues, adopted after 1992, is certainly flexible, but it leads to incoherent decisions that are rooted in an unascertainable vision of federalism. For example, the equalization agreements reached by Ottawa and two of the Maritime provinces in 2005 afford the latter what some Western provinces have been requesting for years. ${ }^{42}$ Why the difference?

Some argue that the eventual integration of the federal government as member of the Council would make it difficult for Ottawa to back down from a decision reached by an institution to which it is part. However, as one commentator puts it, "it is hard to imagine that the federal government would voluntarily constrain its ability to use its unilateral powers by abiding by a process it was not involved in designing." 43

Again, a truly collaborative model of federalism also involves a partnership between the provinces themselves where intra- and interprovincial issues are at stake. Such matters should be as much a priority as federalprovincial issues on the agenda of the Council. In fact, they have proven to be a very secondary concern. The main purpose of the Council has rather been to build common fronts against what the provinces considered unconstitutional incursions by the central government in their own affairs. Provinces do not seem eager to establish binding mechanisms that could ensure the implementation of their agreements over interprovincial matters.

All in all, the competitive model of federalism seems to hold sway over the collaborative model..$^{44}$ I will leave the final word on this subject to Peter Meekison, Hamish Telford, and Harvey Lazar:

The premiers often talk the language of collaboration, but if we read between the lines, some of them seem to be saying only that they need more fiscal resources from Ottawa. And the federal government at times appears to be seeking a level of policy influence on provincial or joint programs that exceeds its fiscal contribution .... [I]nterdependence is likely to remain with us, and will probably 
grow. But it would seem that the various governments of Canada are almost as wary of institutionalizing collaborative federalism as they are of mega-constitutional change. Collaborative federalism thus remains a work in progress. ${ }^{45}$

As we will now see, the Council also suffers from lacking any deep democratic grounding.

\section{The Council of the Federation's Democratic Deficit}

Whether the Council embraces a collaborative or competitive model of federalism, it remains an institution of executive federalism. As do all such institutions, it suffers from a democratic deficit. Nothing in the founding agreement requires the premiers to submit their proposals to the scrutiny of their respective legislatures before their discussion by the Council. Neither is there an obligation to have the legislatures examine the agreements once the thirteen premiers have reached them. To my knowledge, in Quebec, neither the role, mandate, nor the very usefulness of the Council of the Federation were formally debated in the National Assembly, even though the opposition requested it adamantly.

Furthermore, if the Council is to work towards the implementation of a collaborative model of federalism, premiers should be held primarily accountable to one another. Yet as a matter of fact, this is not the case; and as a matter of law, it should not be the case. According to our Westminster style of governance, premiers are held accountable to their local legislatures and their constituents. Premiers have no mandate to deal with national issues. They may claim that they do, but as one commentator puts it, "local issues shape votes," and premiers know that quite well. ${ }^{46}$ And so the life span of a premiers' consensus will be very short should it go against the will of a province's constituents.

The Council's very existence raises a more important problem: that its presence might endanger any future Senate reform. The reason for this is that it is an institution that only serves to reinforce the executive power. Hence, the premiers might not wish to pursue a Senate reform agenda that has the potential of making Parliament "more regionally responsive, and therefore more able to bypass provinces." ${ }^{\text {"47 }}$

Nevertheless, premiers will not be able to escape the demands of public accountability for long. As Harvey Lazar puts it, "the more these [intergovernmental] processes generate hard outcomes that matter to people, the more governments will need to give attention to democratic concerns." ${ }^{38}$ Issues of symbolism, recognition and identity are precisely such matters.

\section{The Council of the Federation: An Inappropriate Institution to Deal with Issues of Recognition and Identity}

Executive federalism has met with a lot of success when low-level substantial policy issues are at stake. However, as demonstrated by the demise of the 1987 Meech Lake Accord, it is bound to fail where issues of symbolism, recognition, and identity are concerned. Formal constitutional reforms are the only channels for such matters. In order for symbols to have any value, they must somehow be impervious to change. Only enshrinement in the Constitution provides symbols with the necessary permanency. If I may recall Jane Austen once again, where issues of identity are concerned, one might say that sensibility takes precedence over sense.

Quebec's quest for recognition, as underlined by Richard Simeon, has little to do with adding more heads of power to section 92 of Canada's 1867 federal Constitution:

\footnotetext{
Quebec's search for recognition is not primarily about whether the province can exercise this or that new responsibility, or about the desire for more cooperative intergovernmental relations. It is inescapably constitutional, focused on the fundamental recognition of a multinational Canada and on an associated distinct role for Quebec.... Quebec's concerns are not about
} 
the mechanics and institutions of federalism, but about the very principles that underlie it. ${ }^{49}$

The parallel health accord successfully negotiated by Quebec in 2004 is an undeniable feat accomplished by the Quebec government. ${ }^{50}$ I do not wish to underestimate its success. Nonetheless, the fact that Jean Charest's colleagues did not want to see their federalist friend bite the dust so early in his mandate, the fact that then-Prime Minister Martin and his minority government wished to cajole part of the dissatisfied Quebec electorate back into the Liberal fold, and most importantly, the soft law character of the agreement were certainly determining elements in that success. Moreover, the vulnerability of these soft law agreements to legislative intervention makes them a poor substitute for a formal constitutional amendment.

The citizens of the western provinces also have their own qualms about the central government, and the Council fails to capture the essence of these demands. More intergovernmentalism is not the answer to their request for Senate reform. Most citizens of Western Canada do not seek recognition of greater power for the provinces. Rather, their wish is to reinforce the central government's institutions by making them more sensitive to regional concerns and therefore more legitimate:

It is unlikely that many western Canadians will see greater intergovernmentalism as an effective or appealing alternative to Senate reform. Such reform is targeted to strengthen the regional voice within Parliament. Thus the Senate reform debate is only loosely connected to steps that might be taken to improve intergovernmental relations..$^{51}$

The Council, I fear, will not be able to make any breakthrough in matters of recognition and identity. By way of conclusion, I will examine how the Council could perform a more useful task within the federation.

\section{Some Suggestions to Improve the Efficiency of the Council}

Arguably, the Council could become a more useful institution, if its mandate were narrowed and if it could be sufficiently informed by democratic scrutiny and public debate. First of all, instead of primarily tackling federal-provincial issues, the Council should devote more energy to finding ways to improve both intra- and interprovincial policy issues. The European Union's Open Method of Coordination (OMC) could be a path to follow. It enables member states of the European Union to deal jointly with issues of common interest in situations where they "do not yet want common legislation in a given sphere but nevertheless have the political will to make progress together." ${ }^{52}$ In the words of a commentator, the OMC is a soft law mode of governance that "reconcile[s] a common approach with the national prerogative for action." ${ }^{33}$ It is a multilateral surveillance mechanism that leads member states to exchange the best practices and to learn from one another. Moreover, the surveillance exercised by all parties provides incentives to achieving common goals in the most efficient manner possible: ${ }^{54}$

Multilateral surveillance, explains Armin Schäfer, researcher at the Max Planck Institute for the Study of Society, rests on peer review, i.e., on the mutual monitoring and evaluation of national policies by other governments. It is targeted at bringing states to behave in accordance with a code of conduct of specific goals, at developing common standards and at acquiring best practices through international comparison. Precisely because there are no sanctions, this mode of governance builds on a co-operative effort to criticize existing policies and generate new ones. In the absence of other means of leverage, any impact on national governments has to result from the (mild) pressure of having to justify one's action in the light of a common evaluation of the compliance of this action with joint goals. ... 55

For instance, the Council's secretariat could gather information on the best practices in the health sector, and provinces could monitor themselves to ensure these practices are 
implemented. In such a situation, the federal government could hardly impose unilateral solutions with respect to that sector without taking cognizance of the work performed by the secretariat. In acting otherwise, the federal government would run the risk of being chastized as arrogant and incompetent.

Naturally, embracing the above idea would not make the Council a stronger institution than it is right now. However, it would enable it to perform a task that stands a good chance of meeting with success. Such success could be enhanced if standing committees for intergovernmental relations were established in the different provinces, and if the public could address submissions directly to the Council. In an article entitled "Inter-Legislative Federalism," David Cameron provides interesting insights on how the role of legislatures and of the wider public in the Canadian intergovernmental system could be reinforced. ${ }^{56}$ As he underlines, Quebec has been the instigator of many of the fruitful innovations he describes.

\section{Conclusion}

The Council, as we have seen, suffers from a number of defects. However, if provincial premiers focused its role on dealing with issues of "sense" - intra- and interprovincial (and to a lesser extent federal/provincial) policy matters - rather than issues of "sensibility" - identity politics - the Council might meet with some measure of success. Finally, such success would only be enhanced if the Council became a truly multilateral surveillance institution along the lines of the European Union's Open Method of Coordination.

\section{Notes}

* Professeur titulaire, Faculté de droit, Université de Montréal, jean.leclair@umontreal.ca.

1 This article is based on a conference delivered at the roundtable "Renewing federal-provincial cooperation in Canada: What can be learned from the EU open method of coordination?" (Institute of European Studies, McGill University/Université de Montréal, February 2005). I gratefully acknowledge the research assistance of Andrée
Boiselle and the editorial help of Marianne Breese. I wish to thank Janna Promislow for her very useful comments.

2 These are, respectively, the main characters of Pride and Prejudice and Sense and Sensibility.

3 Alain Noël, "The End of the Model? Quebec and the Council of the Federation" in Constructive and Co-operative Federalism? A Series of Commentaries on the Council of the Federation (Kingston, ON: Institute of Intergovernmental Relations [IIGR], 2003), online: <http://www.iigr. ca/pdf/publications/313_The_End_of_a_Model_ Quebec.pdf $>$ at 1; J. Peter Meekison, "Council of the Federation: An Idea Whose Time has Come" in Constructive and Co-operative Federalism? A Series of Commentaries on the Council of the Federation (Kingston, ON: IIGR, 2003), online: $<$ http://www.iigr.ca/pdf/publications/311_ Council_of_the_Federatio.pdf $>$ at 3 [Meekison, "Council of the Federation"]; and Ian Peach, "Half Full, at Best: Challenges to the Council of the Federation" (2004) 84 C.D. Howe Institute Backgrounder, online: <www.cdhowe.org/pdf/ backgrounder_84.pdf $>$ at 3.

4 Québec, Secretariat aux affaires intergouvernmentales canadienne, ministère du Conseil exécutif, Council of the Federation - A First Step Towards a New Era in Intergovernmental Relations in Canada, $2 \mathrm{~d}$ ed. (Québec: Gouvernement du Québec, 2004) at 27 (Appendix: Council of the Federation's Founding Agreement), online: <http://www.saic.gouv.qc.ca/ publications/conseil_federation_en.pdf $>[A$ First Step].

5 Ibid. at 21.

6 Constitution Act, 1867 (U.K.), 30 \& 31 Vict., c. 3, ss. 91-92, reprinted in R.S.C. 1985, App. II, No. 5.

7 Furthermore, there are express constitutional exceptions to the exclusivity principle. Some areas of jurisdiction are expressly made concurrent: agriculture and immigration (s. 95), old age pensions (s. 94A), and export from one province to another of the primary production from non-renewable natural resources and forestry resources (ss. 92A (2) and (3)).

8 For an overview of the division of powers in Canada, see Jean Leclair, "Reforming the Division of Powers in Canada: An (Un)Achievable Endeavour?" in Gerhard Robbers, ed., Reforming Federalism - Foreign Experiences for a Reform in Germany (Frankfurt am Main: Peter Lang, 2005) 93. 
9 Friends of the Oldman River Society v. Canada (Minister of Transport), [1992] 1 S.C.R. 3, 1992 CanLII 110; and R. v. Hydro-Québec, [1997] 3 S.C.R. 213, 1997 CanLII 318.

10 See Jean Leclair, “The Supreme Court of Canada's Understanding of Federalism: Efficiency at the Expense of Diversity" (2003) 28 Queen's Law Journal 411 [Leclair].

11 Meekison, "Council of the Federation," supra note 3 at 2.

12 Discussion Paper No. 29: Intergovernmental Cooperation Mechanisms: Factors for Change? (Ottawa: Commission on the Future of Health Care in Canada, 2002) (by Réjean Pelletier), online: Health Canada <http://www.hc-sc.gc.ca/ english/pdf/romanow/pdfs/29_Pelletier_E.pdf $>$ at 4.

13 C.E.S. Franks, "A Continuing Canadian Conundrum: The Role of Parliament in Questions of National Unity and the Processes of Amending the Constitution" in J. Peter Meekison, Hamish Telford \& Harvey Lazer, eds., Canada: The State of the Federation 2002 - Reconsidering the Institutions of Canadian Federalism (Kingston, ON: IIGR, 2004) 35 [Canada: The State of the Federation 2002]; Jacques-Yvan Morin \& José Woehrling, Les Constitutions du Canada et $d u$ Québec du régime français à nos jours (Montréal: Les Éditions Thémis, 1994) at 171-72, 176 (note 147), 178, 191-92, 224, and 235-50.

14 On the diminishing role of Parliament in federalprovincial relations, see Franks, ibid.

15 Herman Bakvis \& Grace Skogstad, "Canadian Federalism: Performance, Effectiveness, and Legitimacy" in Herman Bakvis \& Grace Skogstad, eds., Canadian Federalism: Performance, Effectiveness, and Legitimacy (Don Mills, ON: Oxford University Press, 2002) 3 at 7.

16 Being Schedule B to the Canada Act 1982 (U.K.), 1982, c. 11.

17 Donald Smiley, “An Outsider's Observations of Intergovernmental Relations Among Consenting Adults" in Richard Simeon, ed., Confrontation or Collaboration: Intergovernmental in Canada Today (Montreal: Institute for Research on Public Policy, 1979) 105 at 105.

18 See Leclair, supra note 10, pp. 421-30.

19 Bakvis \& Skogstad, supra note 15 at 14.

20 As underlined by Tom McIntosh, there might be a political price to pay for such direct spending in provincial areas of jurisdiction:

While there may be political credit to be won for creating programs such as the National Child Benefit or the Canada Research Chairs program, this credit diminishes over time and the programs become simply part and parcel of 'what the government does.' Any attempt to shift spending priorities or reallocate resources from those programs to others may come with a political price.

"Intergovernmental Relations, Social Policy and Federal Transfers After Romanow" (2004) 47 Canadian Public Administration 27 at 42 [McIntosh].

21 P.W. Hogg, Constitutional Law of Canada, student ed. (Toronto: Thomson Carswell, 2003) at 160.

22 Reference re Canada Assistance Plan (B.C.), [1991] 2 S.C.R. 525, 1991 CanLII 74.

23 Quotes taken from J.P. Meekison, “The Annual Premiers' Conference: Forging a Common Front” in Canada: The State of the Federation 2002, supra note 13,141 at 145 .

24 Ibid. at 142; see also ibid. at 146.

25 Bob Rae, "Some Personal Reflections on the Council of the Federation" in Constructive and Co-operative Federalism? A Series of Commentaries on the Council of the Federation (Kingston, ON: IIGR, 2003), online: <http://www. iigr.ca/pdf/publications/326_Some_Personal_ Reflection.pdf $>$ at 3.

26 A First Step, supra note 4 at 19.

27 ("This will, for the first time, lead the provincial governments to work in close collaboration at a level never formerly known. That it has not happened before is somewhat surprising.") Quoted in "Conseil de la fédération - Les provinces sont fébriles" La Presse (5 December 2003) A4; "Le Conseil de la fédération permettra de négocier d'égal à égal, croit Charest" La Tribune (5 December 2003) B1.

28 ('It's necessary that this be a counterweight to the federal. That's the goal. But this ought to be done in a positive way. We don't want a negative institution, one that only complains or that engages in 'federal-bashing.") Quoted in "Les PM gardent le cap sur la santé - La création du Conseil de la fédération est reportée au 5 décembre" La Tribune (25 October 2003) B1.

29 A First Step, supra note 4 at 7 (see the section "A Word for the Minister for Canadian Intergovernmental Affairs and Native Affairs").

30 Section 5 of the Founding Agreement states: "The members [of the Council] shall be represented on the Council by their Premier. ..." A First Step, ibid. at 30 .

31 Ibid. at 7 (see the section "A Word for the Minister for Canadian Intergovernmental Affairs and Native Affairs"). 
32 Ibid. at 27 (see the Preamble to the "Founding Agreement").

\section{5).}

42 See "Ottawa conclut une entente avec TerreNeuve et la Nouvelle-Ecosse" Presse Canadienne (28 January 2005); "Martin est sur la défensive après avoir signé l'entente avec T.-N. et la N.-E" Presse Canadienne (14 February 2005); and "Yves Séguin réclame d'Ottawa le même traitement que les Maritimes" Presse Canadienne (15 February 2005). The saga is still ongoing: "Des experts recommandent un compromis pour bonifier la péréquation" Presse Canadienne (5 June 2006). the Mandate and Structure of a Council of the Federation" (October 2003) SIPP Briefing Note (Regina: Saskatchewan Institute of Public Policy), online: University of Regina: <http://www. uregina.ca/sipp/documents/pdf/BN_4_Council_ of_the_Federation_IPeach.pdf $>$ at 4 .

44 McIntosh, supra note 20 at 47: "The new arrangements for managing intergovernmental relations and conflict being proposed - both the Council of the Federation and annual first ministers meetings - appear designed more as vehicles to intensify rather than resolve the disagreements."

45 "The Institutions of Executive Federalism: Myths and Realities" in Canada: The State of the Federation 2002, supra note 13, 3 at 26.

46 Gordon Gibson, "A Council of the Federation" Fraser Forum (November 2003) 8 at 8, online: Fraser Institute <http://www.fraserinstitute. ca/admin/books/chapterfiles/A_Council_of_the_ Federation-Nov03gibson.pdf $>$. See Tom Kent, "An Elected Senate: Key to Redressing the Democratic Deficit, Revitalizing Federalism” Policy Options/ Options politiques (April 2004) 49 at 50:

Their [Premiers] elections are fought on provincial, not national issues. A premier is elected to run the business of the province, not for his or her views on national affairs. . . . It is the democratic deficit in Ottawa, not their own qualifications and mandates, that gives premiers claim to act as national politicians.

47 Richard Simeon, "Federal-Provincial Relations" in The Canadian Encyclopedia (Toronto: Historica Foundation of Canada, 2006), online: <http:// www.thecanadianencyclopedia.com/index.cfm?P $\mathrm{gNm}=\mathrm{TCE} \&$ Params=A1ARTA0002749>. See also Roger Gibbins, "The Council of the Federation: Conflict and Complementarity with Canada's Democratic Reform Agenda" in Constructive and Co-operative Federalism? A Series of Commentaries on the Council of the Federation (Kingston, ON: IIGR, 2003) online: <www.iigr.ca/ pdf/publications/309_The_Council_of_the_Feder. pdf $>$ at 4 [Gibbins].

48 "Non-Constitutional Renewal: Toward a New Equilibrium in the Federation" in Harvey Lazar, ed., Canada: The State of the Federation 1997 - Non-Constitutional Renewal (Kingston. ON: IIGR, 1998) 3 at 25.

49 "Let's Get at the Basic Question Indirectly" Policy Options/Options politiques (January-February 2000) 11 at 13-14.

50 "Asymmetric Federalism that Respects Quebec's Jurisdiction," online: <http://pm.gc.ca/grfx/docs/ QuebecENG.pdf>.

51 Gibbins, supra note 47 at 4.

52 Grainne de Burca \& Jonathan Zeitlin, "Constitutionalising the Open Method of Coordination: What Should the Convention Propose?" CEPS Policy Brief No. 31 (Brussels: Council for European Policy Studies, March 2003), online: University of Pittsburgh <http:// aei.pitt.edu/1980/01/PB31.pdf $>$ at 1, citing the Convention Secretariat.

53 Armin Schäfer, "Beyond the Community Method: Why the Open Method of Coordination Was Introduced to EU Policy-Making" (2004) 8:13 European Integration Online Papers 1, online: <http://eiop.or.at/eiop/texte/2004-013a.htm> at 13.

54 This seems to be what the late Claude Ryan had in mind when he said that "to increase the chances of its success, certain conditions should be met. Among other things, the council should: ... pursue objectives that emphasize research, cooperation and joint projects in areas of provincial jurisdiction ...." See Claude Ryan, "Quebec and Interprovincial Discussion and Consultation" in Constructive and Co-operative Federalism? A Series of Commentaries on the Council of the Federation 
(Kingston, ON: IIGR, 2003), online: <http://www. iigr.ca/pdf/publications/316_Quebec_and_ Interprovinci.pdf $>$ at 6 .

55 Armin Schäfer, MPIfG Working Paper 04/5: A New Form of Governance? Comparing the Open Method of Coordination to Multilateral Surveillance by the $I M F$ and the OECD (Köln: Max Planck Institute for the Study of Societies, 2004), online: <http:// www.mpi-fg-koeln.mpg.de/pu/workpap/wp04-5/ wp04-5.html $>$ at 12.

56 In Canada: The State of the Federation 2002, supra note $13,463$. 